DOI: https://doi.org/10.18371/fp.2(34).2019.183576

УДК 332.142 .6

\title{
ЕКОНОМІЧНИЙ МЕХАНІЗМ ЯК ЕФЕКТИВНИЙ ІНСТРУМЕНТ УПРАВЛІННЯ ПРОЦЕСОМ ВИКОРИСТАННЯ ПРИРОДНИХ РЕСУРСІВ
}

\author{
ТКАЧЕНКО Вікторія Вікторівна \\ к.е.н., ст.викладач кафедри менеджменту \\ Сумський національний аграрний університет \\ ORCID ID: http://orcid.org/0000-0002-2924-4012 \\ e-mail:viktoriyatk@gmail.com
}

Анотація. Розглянуто сутність поняття «економічний механізм використання природних ресурсів»; узагальнено його завдання, принциии та структуру; розглянуто особливості його елементів. Досліджено та проаналізовано роль та вплив економічного механізму на управління процесом використання природних ресурсів.

Ключові слова: економічний механізм використання природних ресурсів, природні ресурси, управління природними ресурсами.

Постановка проблеми. Однією 3 найбільших гострих і складних проблем на сьогодні постає раціональне використання, відтворення та охорона природних ресурсів від забруднення, деградації та виснаження.

В процесі соціально-економічного розвитку країни виникає необхідність пошуку нових якісних підходів до вирішення проблем охорони навколишнього середовища й раціонального використання природних ресурсів сільськогосподарськими підприємствами, екологізації виробництва, підвищення родючості грунтів, зменшення забруднення водних і повітряних ресурсів, збереження й відновлення лісових ресурсів.
Аннотация. Рассмотрено суть понятия «экономический механизм использования природных ресурсов»; обобщено его задачи, принципь и структуру; рассмотрены особенности его элементов. Исследована и проанализирована роль и влияние экономического механизма на управление проиессом использования природных ресурсов.

Ключевые слова: экономический механизм использования природных ресурсов, природныле ресурсы, управление природными ресурсами.

Аналіз останніх досліджень та публікацій. Проблемам раціонального використання природних ресурсів присвячені роботи Л. Абалкіна, А. Аксененко, Т. Беня, І. Булеєва, Б. Буркинського, О. Василика, В. Голяна, Р. Дубаса, Я. Коваля, В. Міщенко, Л. Мельника, В. Степанова, А. Турило, А. Шеремет, М. Чумаченко, С. Харичкова, М. Хвесик та ін.

Мета статті. Метою статті $\epsilon$ визначення необхідності та удосконалення економічного механізму як ефективного інструменту раціонального управління процесом використання природних ресурсів.

Виклад основних результатів. Реформування економічних відносин в 
аграрній сфері неможливе без відтворення природних ресурсів, що потребує удосконалення нормативноправового забезпечення, економічних інструментів та методів, інформаційного забезпечення для підвищення ефективності виробництва сільськогосподарських підприємств з урахуванням екологічних аспектів.

Розвиток суспільних відносин та удосконалення знарядь праці стали причиною більш інтенсивного використання природних ресурсів, особливо в сільському господарстві. Задоволення людських потреб вимагає залучення все більших обсягів природних багатств у виробничий процес, супроводжується нераціональним і виснажливим їх використанням, підвищеними нормами скидів забруднюючих речовин у навколишнє середовище, що має негативний відбиток на життя та здоров'я людей.

Використання природних ресурсів у сільськогосподарському виробництві характеризуються розвитком продуктивних сил, зростанням обсягів їх використання, особливо землі, й темпами забруднення навколишнього середовища, погіршенням здоров'я працездатного населення, зниження продуктивності праці.

Соціально-економічне зростання обумовлюється наступним:

збільшенням обсягів залучення природних ресурсів у сільськогосподарське виробництво без зміни ефективності їх використання;

збільшенням обсягів залучення природних ресурсів у сільськогосподарське виробництво 3 підвищенням ефективності їх використання; підвищенням ефективності використання природних ресурсів у сільськогосподарському виробництві без нарощування їх обсягів.

Перспективним напрямом економічного зростання $\epsilon$ третій - інтенсивне зростання. Перший напрям - класично екстенсивний $\epsilon$ найбільш виснажливим для природних ресурсів, але на сьогодні переважає другий - перехідний.

Треба зазначити, що повний перехід на інтенсивний напрям розвитку потребує значних змін в економічному механізмі використання природних ресурсів сільськогосподарськими підприємствами, запровадження прогресивних відносин на конкурентних засадах 3 обов'язковим урахуванням природоємності.

Нераціональне використання природних ресурсів, особливо в сільському господарстві, «веде до їх виснаження; погіршення якісних характеристик у результаті експлуатації. Відбувається зниження родючості земель, деградація і знищення лісів, порушення режиму водних систем та їх забруднення, трансформація рельєфу» [43, c.50].

Невідповідність темпів економічного розвитку вимогам екологічної безпеки, пріоритетність природомістких галузей, висока питома вага ресурсо- i енергомістких застарілих технологій в сільському господарстві, сировинна орієнтація експорту, а також низький рівень екологічної культури і споживання ведуть до поглиблення кризових явищ в економіці, погіршення стану навколишнього середовища.

«Сучасний тип еколого-економічного розвитку визначається як тех- 
ногенний, що базується на використанні штучних засобів сільськогосподарського виробництва, створених без урахування економічних обмежень» [1, с.135]. «Технократична концепція національного сільського господарства, яка грунтується на кількісному нарощуванні технічних, агрохімічних факторів інтенсифікації сільськогосподарського виробництва, на застосуванні індустріальних технологій і максимальному залученні їх до використання природних ресурсів, не забезпечила адекватного підвищення його ефективності. Дана концепція зумовила надмірні негативні антропотехногенні навантаження на природу, підірвала відновлювальні й саморегулюючі iii можливості останньої» [2, с.7]. При цьому «завдається економічний збиток, що $є$ вартісною оцінкою деградації природних ресурсів і забруднення навколишнього середовища під впливом антропогенних факторів. Такий тип розвитку направлений на боротьбу 3 негативними екологічними наслідками економічного розвитку, а не 3 причинами їх виникнення» [3, с.41].

Одним 3 напрямів подолання еколого-економічної кризи $є$ побудова таких економічних відносин в суспільстві, які б сприяли змінам в структурі сільськогосподарського виробництва через запровадження ресурсозберігаючих, маловідходних, екологічно чистих технологій та модернізації сільськогосподарської техніки.

Позитивні зміни в економіці можуть бути досягнуті шляхом запровадження ефективної політики щодо подальшого розвитку сільського господарства і сільськогосподарських підприємств в цілому. До засобів втілення такої по- літики можна віднести інвестиційну діяльність, систему економічних стимулів з боку держави (пільгове оподаткування, кредитування, субсидування), удосконалення правової бази.

Економічний механізм використання природних ресурсів сільськогосподарськими підприємствами $\epsilon$ ефективним способом регулювання ресурсокористування в аграрній сфері, розвиток якого полягає у відшкодуванні збитків при техногенних природних катастрофах, проведенні їх оцінки; запобіганні збитків; забезпеченні правового та економічного захисту виробничої діяльності; підвищенні відповідальності за підвищення ризику.

На думку Мельника Л.Г., «економічний механізм - це сукупність економічних структур, інститутів, форм i методів господарювання, за допомогою яких реалізуються чинні в конкретних умовах економічні закони та здійснюється погодження і корегування суспільних, групових і приватних інтересів» [4, с.458].

Тархов П.В. під економічним механізмом використання природних ресурсів розуміє сукупність форм та методів регулювання (регламентації) сільськогосподарського виробництва шляхом одночасного використання ринково орієнтованих адміністративних, економічних i соціальних методів управління [5, с.78].

Голян В.А. [6, с.6] розглядає економічний механізм використання природних ресурсів як «сукупність форм, методів та способів регулювання використання природних ресурсів та охорони навколишнього природного середовища». Дубас Р.Г. [1, с.363] вважає, що економічний механізм ви- 
користання природних ресурсів сільськогосподарськими підприємствами є сукупністю взаємопов'язаних методів і важелів, «орієнтованих на раціоналізацію використання природних ресурсів і охорону навколишнього середовища при розширенні масштабів їх використання або орієнтація на стабілізацію і скорочення масштабів використання природних благ».

Ми вважаємо, що економічний механізм використання природних ресурсів сільськогосподарськими підприємствами - це система взаємопов'язаних інструментів і важелів, спрямованих на встановлення ефективної експлуатації природних ресурсів 3 урахуванням оптимального їх використання та відтворення.

Нині виділяють такі типи економічного механізму використання природних ресурсів сільськогосподарськими підприємствами:

- спрямований на ліквідацію негативних екологічних наслідків, а не на причини виникнення екологічних змін, який має незначний вплив на темпи та масштаби розвитку галузей сільського господарства, майже не стримуючи їх діяльності;

- стимулюючий розвиток екологозбалансованих та природоохоронних підприємств в аграрній сфері, який сприяє підвищенню сільськогосподарського виробництва на базі нових технологій, дозволяє покращити використання та охорону природних ресурсів (наприклад, розвиток біологічного землеробства);

- не сприяє розвитку сільськогосподарських підприємств у напряму розширення їх природного базису, перед- бачаючи економне використання природних ресурсів.

Треба зазначити, що жоден 3 типів економічного механізму використання природних ресурсів сільськогосподарськими підприємствами не існує у чистому вигляді.

Пропонуємо виділити такі основні елементи економічного механізму використання природних ресурсів сільськогосподарськими підприємствами:

- ціноутворення з урахуванням екологічного фактору;

- економічні інструменти природоохоронної діяльності;

- система фінансування природоохоронних заходів;

- платність використання природних ресурсів;

- екологічне страхування;

- економіко-екологічне регулювання.

У загальному вигляді сучасний економічний механізм використання природних ресурсів сільськогосподарськими підприємствами можна представити блок-схемою, зображеною на рис. 1.

В Україні досить довго існувало поняття “безкоштовності" природних ресурсів або їх мінімальної ціни. Саме у відсутності реальних цін на природні блага і полягає основна проблема використання природних ресурсів, що сприяло нераціональному та безгосподарському їх використанню» [7, с.67].

Платежі підприємств до фондів охорони навколишнього середовища не в повній мірі сприяють раціональному використанню природних ресурсів.

Складовими ціни на природні ресурси є ціни на сировину, матеріали, 
енергію; платежі за право користуватися землею, водою, лісом та іншими природними ресурсами; платежі за використання асиміляційного потенці- алу екосистем (за забруднення); орендна плата за використання основних фондів, у тому числі природоохоронного призначення.

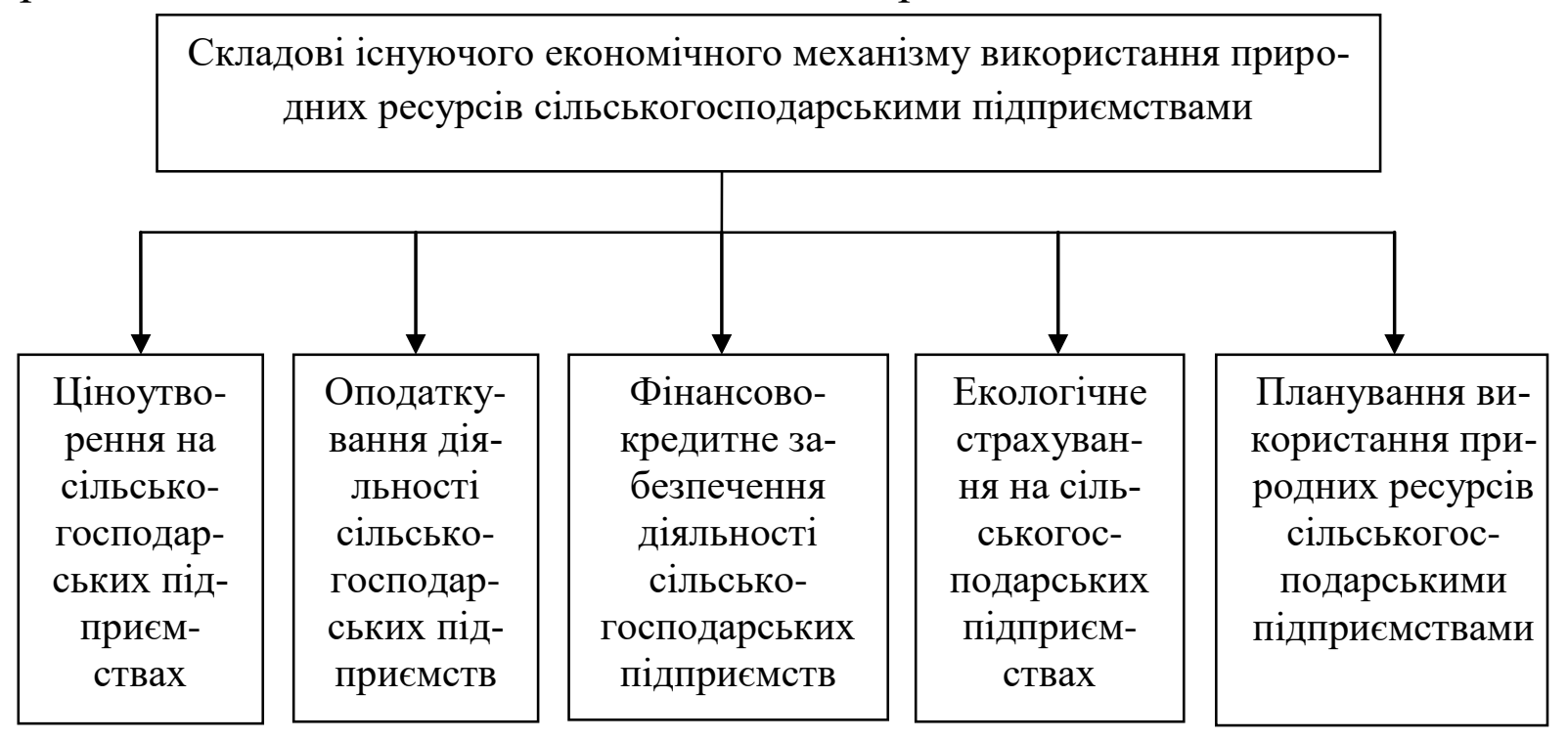

Рис.1 Блок-схема складових існуючого економічного механізму використання природних ресурсів сільськогосподарськими підприємствами Джерело: узагальнено автором

Більшість науковців схиляються до думки, що реальні ціни природних ресурсів можуть стати ефективним важелем в ринковому механізмі і навпаки, при нераціональному використанні природних ресурсів на сільськогосподарських підприємствах їх облік призведе до погіршення виробничих показників, що прямо відзначиться на фінансових результатах.

Будь-які операції щодо купівлі чи продажу землі пов'язані із встановленням ціни на неї, яка в свою чергу залежить від родючості земельної ділянки, а також іiі місця розташування. Отже, ціна на землю залежить не від іiі вартості, а від того доходу, який приносить земля своєму власнику в процесі експлуатації, тобто від ренти, яка ще й слугує ланцюгом поєднання 3 економічною оцінкою використання земельних ресурсів [8, с.23].
Важливу роль у системі економічних інструментів використання природних ресурсів сільськогосподарськими підприємствами відіграє податкова політика, яка передбачає стягнення платежів за право користування природними ресурсами (наприклад, за користування земельними ресурсами для сільськогосподарських підприємств встановлюється плата у вигляді земельного податку, або орендної плати); платежів на відтворення та охорону природних благ; компенсаційних платежів за вибуття природних ресурсів 3 цільового використання чи погіршення їх якості (наприклад, платежі за вилучення 3 обігу сільськогосподарських земель); платежів за забруднення природного середовища (за викиди в атмосферу забруднюючих речовин від стаціонарних джерел та тра- 
нспорту, скиди стічних вод у водні об'єкти, розміщення відходів тощо).

Одним 3 основних податків, який сплачується в залежності від наявності у платника земельної ділянки є плата за землю.

Плата за землю є прямим податком на володіння або користування земельною ділянкою, який стягується або у вигляді земельного податку, або орендної плати. Орендна плата визначається в залежності від грошової оцінки 1 га певного виду земельної ділянки.

До платників земельного податку належать як юридичні так і фізичні особи, які мають земельну ділянку у власності або користуванні, в тому числі на умовах оренди. Тобто, земельний податок $є$ комбінованим податком відносно його класифікації в залежності від суб’єктів оподаткування.

Розмір плати за землю фактично визначається площею земельної ділянки та грошовою оцінкою 1 га земельної ділянки і не залежить від результатів виробничо-господарської діяльності платника. Розрахунок суми земельного податку здійснюється виходячи із загальної суми податку на поточний рік станом на 1 січня наступного року.

Завданням податкової політики в сфері використання природних ресурсів сільськогосподарськими підприємствами є зниження податкового тиску на них, спрощення податкового обліку та підвищення його прозорості й достовірності, оптимізація строків сплати податків, створення сприятливих умов для аграрних товаровиробників. Зниження податкового тиску частіш за все реалізується через встановлення податкових пільг, які мають надаватися 3 урахуванням рівня проведення приро- доохоронних заходів, екологізації виробничої діяльності. Зменшення ставки оподаткування повинно застосовуватися для ресурсозберігаючих та маловідходних технологій. За підвищеною ставкою необхідно оподатковувати діяльність сільськогосподарських підприємств, які використовують шкідливі, озоноруйнуючі препарати, пестициди, енергоємну техніку тощо.

Важливе значення мають "зелені" (екологічні) податкам, які дозволяють зробити вартість сільськогосподарської продукції більш адекватною по відношенню до витрат, а також сприяти компенсації екологічного збитку самим забруднювачем, а не всім суспільством (реалізація принципу “забруднювач платить”).

Сучасна податкова система спрямована на стягнення податків 3 доходу, доданої вартості та ін. Плата за використання природних ресурсів складає декілька відсотків від доходної частини бюджету, заохочуючи до природоексплуатуючої діяльності. На нашу думку, доцільною $є$ зміна пропорцій на користь підвищення питомої ваги податків, пов'язаних 3 використанням природних ресурсів, перш за все, плати за право користуванням ресурсами, “зелених" податків. Доцільно впровадити податкові стимули в сільському господарстві для заохочення до екологізації діяльності сільськогосподарських підприємств (рис.2).

Вважаємо, що принцип платного використання природних ресурсів повинен реалізовуватися за такими напрямами:

- введення плати за придбання у власність природного ресурсу; 
- плата за використання природного pecyрсу, за негативний вплив, погіршення його стану.

До заходів удосконалення економічного механізму використання природних ресурсів сільськогосподарськими підприємствами в сфері оподаткування слід віднести скорочення переліку шкідливих речовин, за які стягуються платежі й підвищити нормативну плату за скиди найшкідливіших з них; закласти в основу розрахунків плати за забруднення залежність між розміром плати й величиною загальних витрат сільськогосподарських підприємств; не враховувати розмір плати за забруднення навколишнього середовища у собівартості продукції; запровадити порядок стягнення платежів за лімітне та понадлімітне забруднення навколишнього середовища безпосередньо 3 прибутку сільськогосподарських підприємств; запровадити податкові пільги шляхом врахування в платежах за забруднення коштів, які були спрямовані підприємством на здійснення природоохоронних заходів, запровадження ресурсозберігаючих та маловідходних технологій.

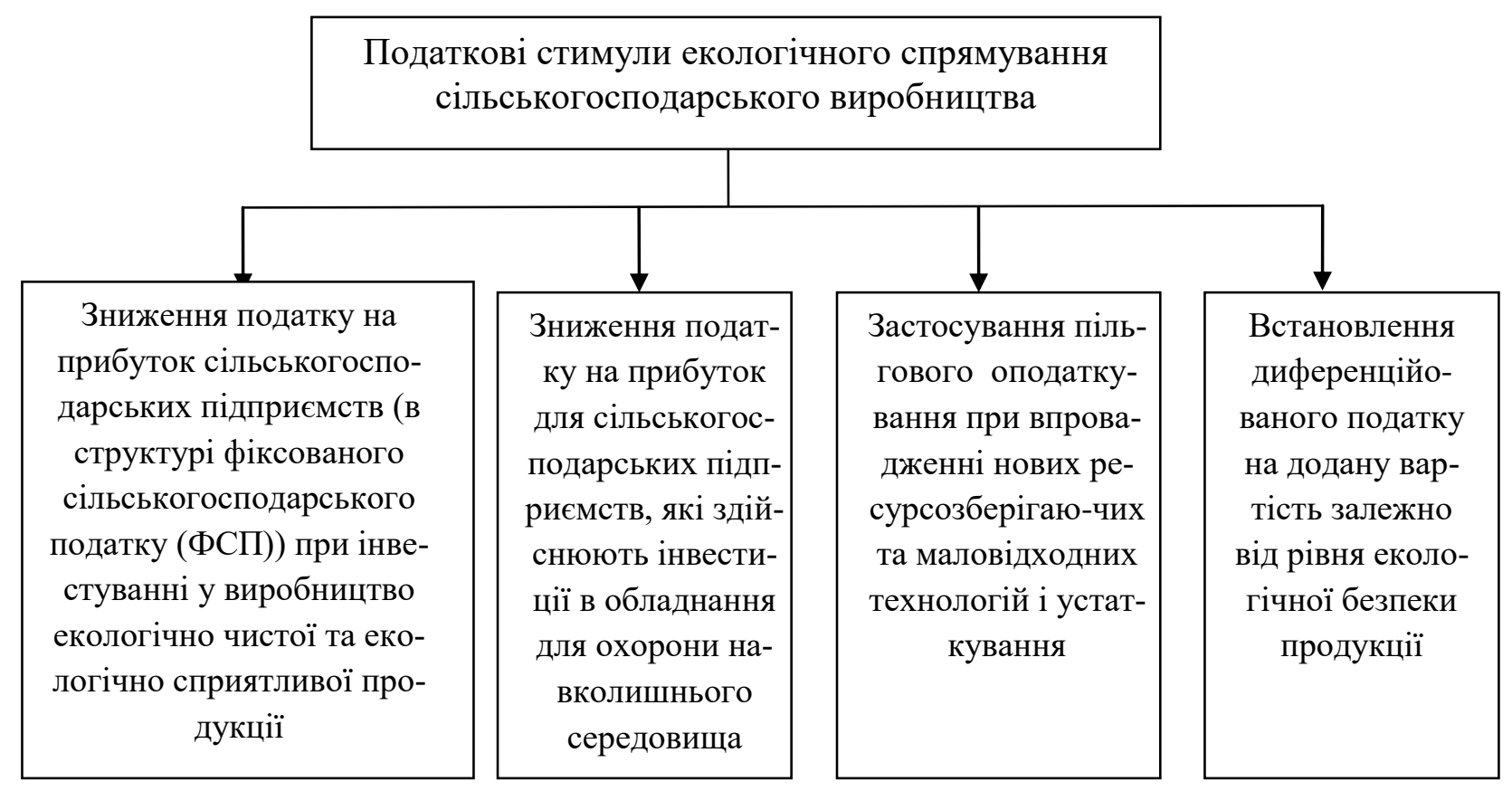

Рис.2. Блок-схема податкових стимулів екологічного спрямування сільськогосподарського виробництва Джерело: власні розробки автора

Важливе значення в системі платного використання природних ресурсів в сільському господарстві має надаватися штрафам, санкціям за нераціональне використання природних ресурсів сільськогосподарськими підприємствами та забруднення навколишнього середовища. У випадку вилучення зе- млі через іiі нераціональне використання, забруднення повітря чи води понад встановлених нормативів, необхідно застосовувати економічні та правові важелі боротьби 3 порушниками. Доцільно удосконалити систему штрафних санкцій при порушенні 
умов використання природних ресурсів підприємствами.

Діючий економічний механізм не створює передумов для повноцінного фінансування поточних витрат на раціональне використання природних ресурсів сільськогосподарськими підприємствами та їх відтворення [9, с. 369]. Результативність фінансового забезпечення поточних витрат залежить від повноти та своєчасності сплати зборів за забруднення навколишнього середовища, а також від фінансової спроможності сільськогосподарських підприємств. Нині за забруднення довкілля не компенсують економічний збиток у повній мірі.

Відшкодування збитку передбачає відшкодування шкоди за забруднення навколишнього середовища окремим суб'єктам господарювання, в тому числі й населенню. В даному випадку йдеться не про пряме відшкодування шкоди безпосередньо населенню, а про опосередковане - шляхом проведення компенсаційних заходів (будівництво лікарень тощо). Кошти, які залишились необхідно спрямовувати на природоохоронні програми державного та регіонального значення, збереження та відтворення природних ресурсів, створення об'єктів для утилізації відходів, розвиток нових екологічно орієнтованих технологій тощо. Тоді буде здійснюватися кругообіг цих грошових коштів у сфері сільськогосподарської діяльності.

Суттєвого покращення потребує «система державних субсидій для сільського господарства. Нині вона не в повній мірі сприяє раціональному використанню природних ресурсів сільськогосподарськими підприємст- вами, бо спрямована на фінансування виробників неефективної сільськогосподарської техніки, субсидування природоємних проектів, глобальних та нераціональних заходів зі зрошення та осушення земель, закупівлі мінеральних добрив та пестицидів» [10, с. 33].

Недоліком системи фінансування природоохоронних заходів $є$ те, що більша частина інвестицій надходить 3 Державного бюджету i залежить, як правило, від економічної ситуації в країні, а не від потреб відтворення природних ресурсів. Для поліпшення ситуації пропонуємо залишати державні інвестиції на охорону природи в бюджеті (для фінансування масштабних національних та регіональних програм), а для фінансування поточних витрат - формувати цільові фонди, які грунтуються на платежах за забруднення, штрафах за порушення природоохоронного законодавства.

Важлива роль у формуванні ефективного економічного механізму використання природних ресурсів сільськогосподарськими підприємствами належить державі, бо саме вона встановлює основні напрями, параметри і порядок їх застосування, пріоритетними з яких $\epsilon$ охорона i раціональне використання конкретного виду природного ресурсу сільськогосподарськими підприємствами. Одним 3 найважливіших завдань здійснення державної політики є забезпечення стійких міжнародних зв'язків 3 іншими країнами у сфері економіки та зарекомендувати себе як стабільну, розвинуту державу.

Висновки. На сучасному етапі в економіці України застосовуються різні типи економічних механізмів ви- 
користання природних ресурсів з різним ступенем їх розробки, але доцільно розробити економічний механізм використання природних ресурсів сільськогосподарськими підприємствами. Удосконалення потребують складові існуючих його елементів: оподаткування, страхування, інвестування у інноваційні технології використання природних ресурсів та інші.

\section{Список використаної літератури}

1. Дубас Р.Г. Економіка природокористування. К.: «МП Леся». 2007. 448c.

2. Новаковський Л.Я. Соціально-економічні проблеми сучасного землекористування. К.: Урожай. 2007. 276с.

3. Доннік Т.С. Економічний механізм стимулювання в системі раціонального використання природних ресурсів. Вісник СДАУ. Сер.Економіка і менеджмент. 2004. Вип. 3-4. С.40-42.

4. Мельник Л.Г., Шапочка М.К. Основи екології. Екологічна економіка та управління природокористуванням.: підручник. Суми: ВТД «Університетська книга». 2006. 759c.

5. Тархов П.В. Критерии государственного регулирования экономики: Монография. Сумы: ВВП «Мрія-1». 2005. 268 с.

6. Голян В.А. Економічний механізм природокористування / В.А.Голян //Агросвіт. - 2007. - №8. - С.5-12.

7. Бобылев С.Н., Ходжаев А.Ш. Экономика природопользования: учебник. М.: ИНФА-М. 2004. 501c.

8. Ульянченко О.В. Ресурсний потенціал аграрного сектора економіки України: управлінський аспект. Суми: Довкілля. 2009. 383 с.

9. Семишкур В.В. Еколого-економічні аспекти раціонального використання земельних і водних ресурсів. Вісник Сумського національного аграрного університету. Серія «Економіка та менеджмент». 2007. № 6-7 (26-27). С.368-372.

10. Семишкур В.В. Економічний механізм використання природних ресурсів сільськогосподарськими підприємствами. Агросвіт. 2009. № 21. С.32-35. 